\title{
Community Empowerment Communication Model in Urban Agricultural Management in the City of Bandar Lampung
}

(Study in Maju Jaya Group, Pinang Jaya Village, Bandar Lampung City)

\author{
Anna Gustina Zainal ${ }^{1, *}$ Toni Wijaya ${ }^{2,}$ Vito Frasetyat ${ }^{3,}$ Nadya Amalia Nasution ${ }^{4}$,
}

Helvy Yanfika ${ }^{5}$

\author{
1, 2,3 Department of Communication, Universitas Lampung \\ ${ }^{4}$ UIN Raden Intan Lampung \\ ${ }^{5}$ Department of agribusiness, Faculty of Agriculture, University of Lampung \\ *Corresponding author. Email: anna.gustina@fisip.unila.ac.id
}

\begin{abstract}
Community empowerment is one of the efforts to improve community welfare through several activities, including increasing community initiatives and self-help, developing economic enterprises, and activities that can increase the community's ability to increase their production. Community empowerment is as important as increasing knowledge, broadening insight, and improving the apparatus (bureaucrats) for implementing programs following their respective functions and professions. The Community Empowerment Communication Model through urban farming was studied in the Maju Jaya Group, Pinang Jaya Village, Bandar Lampung City. This type of research carried out in this study is a descriptive qualitative method. This study found that the community empowerment model through the concept of urban farming in the Maju Jaya Group, Pinang Jaya Village, Bandar Lampung City has been running well. However, some unfulfilled needs can become problems or obstacles in empowering the Maju Jaya Farmer Group; this is seen by using the CIPOO approach (Context, Input, Process, Output, Outcome) already running quite well. In addition, development communication is carried out to empower farming communities with njagong and word of mouth communication between residents or known as the Word of Mouth. Word of Mouth (WoM) is providing informal socialization to citizens while chatting together. Word of Mouth is a form of word of mouth, which costs little or no cost. That is a traditional community the element of closeness conveying also influences whether the message is received.
\end{abstract}

Keywords: Community empowerment, communication model, urban farming, Farmer

\section{INTRODUCTION}

The environmental aspect is one of the components that are the primary considerations in spatial planning activities. This is so that decisions taken in spatial planning for the benefit of development can be sustainable and do not cause new problems economically, socio-culture, and physical environment
[1]. Various changes in environmental conditions can adversely affect humans. Various forms of ecological destruction, such as air pollution, water pollution, and decreased environmental quality due to natural disasters [2], of course, can have a global impact on the environment [3], especially on the health of the community itself. Environmental aspects are one of the 
components that become primary considerations in spatial planning activities.

This is so that spatial planning decisions can be sustainable and do not cause new problems economically, socio-culture, or physically. Until now, the use of space is still not by expectations, namely the creation of a comfortable, productive, and sustainable space [4]. Community empowerment is one of the efforts to improve community welfare [3], [5], through several activities, including increasing community initiatives and self-help, developing economic enterprises, and expanding the community's ability to increase their production. Community empowerment is as important as increasing knowledge, broadening horizons, and improving the apparatus (bureaucrats) [6] to implement programs following their respective functions and professions. This empowerment can provide opportunities for the community to show characteristics as a constructive community [7].

Since the enactment of Law Number 23 of 2014 concerning regional governance, it has increasingly emphasized that local governments are directed to accelerate the realization of community welfare and provide opportunities for local governments to develop their regional potential. In line with this, there needs to be innovation and creativity by local governments in improving the welfare of local communities, especially in the economic field [6]. The city government of Bandar Lampung has made programs to enhance community welfare based on community empowerment. Based on BPS Kota Bandar Lampung data, the population in Bandar Lampung has continuously increased; this is due to the large number of residents coming.

In line with Regional Regulation number 07 of 2002 concerning the management of green open spaces, including green agricultural areas as a form of green open space, Article 8 states that green agricultural regions are used for food $\&$ horticultural crops. The concept of urban agriculture is a program initiated to maintain the quality of life [8], namely by continuing to consume healthy foods made from quality fish and vegetables in urban areas. This program is designed to be developed in dense cities that do not have many vacant lands. In addition, urban agriculture helps contribute to urban green open spaces and food security [1].

This farmer group is a non-governmental group that is incorporated and grows based on familiarity, harmony, and shared goals to increase business productivity in urban agriculture-driven by awareness and a strong desire as well as an effort to assist government programs in empowering the community so that it can increase family income, especially in RW 08 Kelurahan Pinang Jaya. In addition to farming vegetables, the Maju Jaya Group also manages various cultivations, namely the cultivation of Oyster Mushrooms, Cricket cultivation, and Catfish cultivation, whose seeds originally came from the Agriculture Service. After obtaining sources from the Department of Agriculture and cultivating them, the group members made various processed products.

The progress of the Maju Jaya Group cannot be separated from the role of the Bandar Lampung City Agriculture Office, which continues to provide guidance and guidance with various training and assistance for agricultural cultivation, fisheries, and animal husbandry. At the same time, contribution in the field is carried out by Field Agricultural Extension (PPL) from the Agricultural Service of Bandar Lampung City, which is assigned to the Bringin Jaya District. The Department of Agriculture also provides facilities to market agricultural products from the Maju Jaya Group, namely by participating in the Farmers Market, Agricultural Product Title held once a month at the Kalpataru Field in Bandar Lampung, a bazaar or other activity.

A reforming agent in a society that is being empowered is essential [7], [9] because the reformer agent can later determine how the empowerment is carried out. In the charge carried out through urban farming, the role of agent for reform is a farmer group in Pinang Jaya Village named the Maju Jaya Farmers Group. In the Maju Jaya Group as a reformer agent, in its institutional context, it has made a work plan program for one period (3 years) as a reference so that the activities carried out can be planned, directed, and carried out following the shared vision, mission and goals. The organizational structure has been prepared following the Pinang Jaya Urban Village Decree number: 26/2011 but the duties and functions of each division have not yet been formulated, and the Statutes/Bylaws (AD / ART) have not been prepared. In terms of human resources in the Maju Jaya Group, it is felt that it is not optimal because the members of this farmer group experienced a decline in 2011 by 26 members and in 2020 to 32 members. However, not all members are active in the association; this is due to the mindset of the City community who have not realized and think that farming is done in rural areas and cannot farm in the middle of the City.

The industrial revolution community is faced with ease in innovation because of easy and inexpensive digital technology networks "online" [10]. They are adopting agricultural innovation as a step in utilizing local ecosystems and educating people in terms of attitudes, behaviors, knowledge, and skills to have strong competitiveness. In the Industrial Revolution 4.0, agriculture needs to adopt innovation through network connections [11], applications to less human work or artificial intelligence, robotics that has replaced humans. Agricultural innovation in the form of appropriate communication technology is needed [9],[12]. In the 
Industrial Revolution 4.0, the farm sector was moving very slowly, "forced" to follow technological developments to improve product quality and production. The innovation adoption program aims to improve agricultural processes better [13] and is oriented to maximum production results [14]. Through the adoption of innovation, development communication enters and has a role in bridging development in the agricultural sector, because development communication opens public understanding pragmatically in carrying out development programs [14],[15] so that the contribution of communication as a shaper of change in society can run effectively and efficiently-development-oriented.

Based on this explanation, this research focuses on a dimension related to community empowerment communication with the formulation of the problem is how the Community Empowerment Communication Model through the concept of urban farming (urban agriculture) is a study in the Maju Jaya Group, Pinang Jaya Village, Bandar Lampung City.

\section{METHOD}

This type of research used in this research is descriptive qualitative research. The research location is in the Maju Jaya Group, Pinang Jaya Village, Bringin Raya District, Bandar Lampung City; the reason for choosing this location is that it is one area that carries out urban agricultural programs with innovations from the community. Data were collected in this study using interview, observation, and documentation techniques [16] with the informants, namely the Head of the Food Crops and Horticulture Section of the Bandar Lampung Agricultural Service, PPL Bringin Raya District, and the Chairperson and members of the Maju Jaya Group. Meanwhile, to collect data sources using the purposive sampling technique. Data analysis was carried out by collecting data, reducing data, presenting data, and drawing conclusions.

\section{RESULT AND ANALYSIS}

\subsection{Community Empowerment Model}

Empowerment will make a significant contribution to people's lives [2],[7],[17]. The gift given includes a variety of knowledge and skills and suitable methods to maximize all the potential in individuals and the potential in their environment. However, empowerment is increasing the ability or capacity to meet the needs of individuals [9],[18] and building a spirit of community independence so that it develops and has a solid motivation to participate in the empowerment process.

An appropriate empowerment model is needed [5],[8]. The suitable empowerment model for improving agents can be stated in a conceptual framework that uses the CIPOO approach (context, Input, process, output, outcome). Researchers used a reformer agent empowerment model approach through the CIPOO approach (context, information, process, work, product) proposed by Sulistyani [19], while the CIPOO approach referred to is:

\section{a. Context}

Context is the context of empowering agent reformers for programs or activities suitable to be developed to empower reformer agents [19]. The program context that needs to be included in the reformer agent empowerment program should consist of:

\section{1.) Institutional Aspects}

In community empowerment in the Maju Jaya Group, Pinang Jaya Village, Bandar Lampung City, the institutional aspect concerning the efficiency of the structure and function will provide a clear line of coordination between the management and members of the Maju Jaya Group as an institution used to accommodate their interests. Based on the results of interviews and observations of researchers related to the institutional structure and function of the Maju Jaya Group, several attempts have been made to make the Maju Jaya Group efficient, including the existence of an organizational chart showing the relationship of cooperation and grouping of job segments. However, the organizational chart becomes less efficient because there is no written performance division and chain of command, so the management works according to their awareness.

The second aspect in institutions is related to how decisions are made and interactive communication. This aspect relates to how decision-making in the organization is carried out and how to communicate between members. Decision-making is a series of process activities carried out in solving a problem [20]. Meanwhile, communication is defined as transferring one's ideas or information to others [21], [22]. Regarding decision making and this method of communication, an agreement was made in community empowerment in the Maju Jaya Group; this can be found through interviews with Maju Jaya Group members.

Everyone who participates in the deliberation is a communicator who conveys orders and messages to carry out work [13],[20]. A job's success or failure depends on communication, so it can be said that communication is an essential factor in the organization [23]; two-way communication carried out through deliberation allows the communication process to run effectively and can create a communicative environment in the organization. The use of participatory management and face-to-face communication is an excellent way to improve communication effectiveness. 


\section{2.) Management System Aspects}

Management system aspects, in this case, including how the organization performs management functions directed at the PAFHIER function [19], which provides policy analysis, finance, human relations, information, external relations [24]. In community empowerment in the Maju Jaya Group, Pinang Jaya Village, aspects of this management system include how the Maju Jaya Group directs the group to produce the work program that has been made, financial sources and allotments, how is the relationship between management and information sources as well as how the Maju Jaya Group establishes cooperative relationships with outsiders.

Based on the results of the interview, related to the work program carried out by the Maju Jaya Group administratively how the work program will be carried out has been arranged, but the work program was not made at the time of the establishment of the Maju Jaya Group but was made in 2013. Based on researchers' observations, the existence of This work program makes the activities carried out more focused and becomes a guideline for the Maju Jaya Group. With the preparation of a work program, it is also very motivating to keep trying so that the goals stated in the work program can be achieved.

The next aspect is how the management's relationship with members and sources of information. In empowering the Maju Jaya Group, this aspect includes how the direction relates to its members and sources of information.

\section{3.) Organizational Aspect}

Based on the interview results, the empowerment of the Maju Jaya Group can be seen by an increase in optimal production and resources. Based on observations from researchers, it is stated that with the limited human resources owned by the Maju Jaya Group, these resources are finally able to achieve optimal results. This is indicated by increased insight or knowledge of members who obtained the training followed and applied in their activities.

The next aspect of organizational performance is productivity. The productivity referred to in empowerment in the Maju Jaya Group is about what the Maju Jaya Group has produced. Based on the interviews and observations of researchers, what has become an advantage in the Maju Jaya Group is cultivating it and processing it into a product worth selling. The Maju Jaya group enables catfish and processes them into catfish nuggets, catfish pizza, Lemper catfish, and catfish shredded. In addition to catfish cultivation, Maju Jaya Group also boosts Oyster Mushrooms and processes them into botok mushrooms, mushroom peppers, mushroom chicken lemper, mushroom satay, and crispy mushroom chips. The Maju Jaya group has run a program from the government, namely urban farming, and processing, to empower the community because the sale of these processed products can improve the community's economy.

The last aspect of organizational performance is about good service quality. Related to this aspect, the Maju Jaya Group is directed to provide good service. A service can be good if the community feels satisfied and there are no complaints about the benefits. The quality of the service supplied to the Maju Jaya Group is when it comes to selling processed catfish and cultivated products.

\section{4.) Mastery Aspects of Empowerment Materials}

The aspect of mastery of empowerment materials in the Maju Jaya group of Pinang Jaya Village, Bandar Lampung city, is about how the organization understands the problems that occur and finds solutions and approaches to achieve community independence. In community empowerment by the Maju Jaya Group, this aspect includes how the Maju Jaya Group understands the work program that has been planned following the predetermined vision and mission. About this aspect, the empowerment material has not been fully mastered by the management of the Maju Jaya Group.

Based on the results of the interview disclosed by Mrs. Ary and the observations of the researcher, it can be seen that the Maju Jaya Group has not yet formed $\mathrm{AD} / \mathrm{ART}$, which is used to guide the implementation of the organization. The performance of several activities in the Maju Jaya Group was not all following what was written in the work program, such as the picket was not carried out according to schedule. However, from the interview, at least the Maju Jaya Group understood the problems that occurred and found a solution by replacing pickets with free time members.

\section{b. Input}

Input is the internal potential possessed by reformer agents and externally related to reformer agents and can contribute to the reformer agent empowerment process [7], [19]. The information describes the resources, facilities needed to empower reform agents, and related resources owned in empowerment in the Maju Jaya Group regarding human resources. Humans as workers are the factors that determine the success or failure of a job.

Based on the results of interviews with Mrs. Ary and Mrs. Nani, the decline in members was due to the mindset of the City community, who did not understand the concept of urban farming. The next aspect is related to the land used for catfish, and oyster mushroom cultivation; based on interviews, the previously empty land was used by the Maju Jaya Group and is now a place for cultivation. After the cultivation results are harvested, they will be processed, the site for production 
is carried out in their respective homes; this is an obstacle for the Maju Jaya Group, the government in assisting always audits how it is implemented if the assistance provided is not in one place it will not be easy to audit it.

About the facilities needed for empowerment in the Maju Jaya Group, the facilities in question are in the form of movable objects and immovable objects such as machines. These machines are used considering that the number of work results according to the device used depends on the device used. The machines used need to be standardized in terms of quality and work capacity and their endurance strength from the point of view of time. The implementation of empowerment in the Maju Jaya Group in the cultivation of Oyster Mushrooms and Catfish uses the Bandar Lampung Agricultural Service facilities and the Ministry of Marine Affairs.

Based on the results of interviews and observations of researchers related to the Maju Jaya Farmer Group facilities, it can be seen that the equipment has supported the production process. However, the obstacle lies in the limited land so that there is no place to be used as a production house; this makes it difficult for the Maju Jaya Group to get assistance from the government.

The third aspect is the sources of finance and their allocation. Money is needed, such as employees' salaries or wages, purchases for production needs, Etc. In this aspect, the management system manages finances in an organization and how the money is allocated. The Maju Jaya Group's financial source comes from cash which is earmarked for maintenance costs for mushroom lumbung, buying new mushroom backlogs, buying catfish feed, cleaning catfish ponds, and expenses if a production machine is damaged. Apart from cash, financial sources are also obtained from interest on loans from the Lampung Provincial Government grant, but money is used for the welfare of its members by taking a vacation at the end of the year; this is payment for members of the Maju Jaya Group who have worked hard and are now getting free holidays.

Internally, the potential resources owned by the Maju Jaya Group have been developed by the Bandar Lampung City Government through the Agriculture Office. Since this internal potential was developed, Kelurahan Pinang Jaya began to be recognized by the wider community. After various efforts made by the facilitator to raise awareness, the next step is mastery of technology and information. As a reforming agent, the Maju Jaya Group excels in being proficient in the field of technology. c. process

The process is all activities or steps in stages carried out in the framework of empowering reforming agents consisting of:

1.) Capacity building approach for institutional empowerment of reform agents

According to Nugroho [26], capacity building means capability. To be given the power or power concerned must first be given a capacity-building program to make them competent. In community empowerment in the Maju Jaya Group, Pinang Jaya Village, Bandar Lampung City, the capacity-building approach is usually carried out by enabling people, organizations, and value systems. Based on researcher observations and interviews, it can be concluded that to allow humans to is marked by a training program to make them skilled in cultivating and producing mushrooms and catfish. In participating in the activity, the Maju Jaya Group always sends two selected members based on the business sector they are running. To enable humans, in this case, the Maju Jaya Group is carried out through technical training, but for administrative training, they have never attended any training at all.

2.) New Public Management (NPM) approach to improve internal managerial capabilities of reform agents.

The concept of New Public Management (NPM) contains seven main components, including professional management in the public sector, performance standards and performance measures, a greater emphasis on controlling outputs and outcomes [27], solving work units in the public sector, adoption. Management style in the business sector into the public sector and an emphasis on discipline and more significant savings in resource use. The Maju Jaya Group of Pinang Jaya Village, Bandar Lampung City, has not been fully implemented using the New Public Management (NPM) approach. The interviews and observations of researchers show that one of the main components in NPM, namely performance measurement, has not been implemented in empowerment in the Maju Jaya Group.

3.) Improved performance to improve the organizational performance of reforming agents.

In addition, in community empowerment in the Maju Jaya Farmers Group, the NPM approach is demonstrated by engaging with its partners. From several interviews that have been conducted, it is known that in improving the managerial and success of the group, the Maju Jaya Group always holds regular meetings every month. In establishing cooperation with its partners, it is carried out through contact with the District PPL. This process is used to obtain the needs needed to implement empowerment in the Maju Jaya Farmer Group. 
4.) Substantial approach through organizing knowledge, attitude, practice (KAP)

Knowledge is defined as intelligence, insight, and knowledge. Meanwhile, attitude is defined as conscious and caring behavior to build [19]. As a reforming agent, the Maju Jaya Group in Pinang Jaya Village of Bandar Lampung City was given various understandings related to suitable cultivation methods, good processing methods, good packaging methods to produce members' satisfaction, and the community. The management must also understand the ever-changing natural conditions and determine the right solution for these conditions. When people are increasingly aware of the importance of adequately carrying out urban farming activities, it will create community independence in land use and production.

\section{d. Output}

This approach sees the output as the final result after a series of empowerment processes is carried out that will achieve competence as a reformer agent who is empowered and capable of implementing assistance to the community to carry out action programs from planning, implementation, monitoring, and evaluation of empowerment programs.

In this empowerment, the Maju Jaya Group as a reform agent in partnership with the government, namely through the agriculture office, health office, East Java provincial government, Ministry of Marine Affairs and Fisheries, and parties and the private sector, namely collaborating with PT. Wahana Perkasa. With the existence of this cooperative relationship, it shows a significant development, which is indicated by the successful harvesting of cultivated products and processing them into several valuable products; the product has obtained a P-IRT permit so that it can be distributed to the public, providing good service so that it can provide satisfaction to members due to increased production. Several aspects related to the outcome of the Maju Jaya Group empowerment process have been previously described as aspects of organizational performance, which include effectiveness, efficiency, productivity, accountability, and service quality.

\section{e. Outcome}

The outcome is the value of benefits generated after the reforming agent has a certain level of empowerment so that the reformer agent can act as a reformer agent by playing a role in the community empowerment process, namely linearly or directly proportional to the level of empowerment it already has. After the output is obtained or materialized, it can show at what level the charge of the reformer agent is located. The story of empowerment that the reforming agent has received will later provide the reformer agent's ability to carry out a community empowerment process. The level of intervention to make changes in community development will be directly proportional to the level of empowerment that has been achieved.

The Maju Jaya group is in stage II, namely as a reformer agent who partners with the government to implement empowerment programs. As a reforming agent, the capacity of the Maju Jaya Group to become an organization that is on a scale has begun to be "heard and taken into account" by its voice. Based on the previous explanation, Maju Jaya Group as a reforming agent is an agent that can be called as establish. Although several shortcomings become obstacles, such as the completeness of the organization as an institution is not yet owned by reform agents. However, with these deficiencies not making the community give up, the Maju Jaya Group continues to innovate by cultivating and processing it into products of the sale value. The enthusiasm and innovation of the Maju Jaya Group have also partnered with various parties, both government and private. With this, the urban farming activities carried out in the Maju Jaya Group continue and can improve the community's economy. Based on the explanation reviewed, it can be said that as a reformer agent, the Maju Jaya Group is already empowered.

Communication is carried out to develop for community development or previously known as a community resource, rural areas development, community economic development, rural revitalization, and community development. Community development is an amalgamation of the concept of community and development [13]. Development, if it is focused, programmed, and properly controlled, will provide solutions to problems related to community welfare issues. The United Nations have voiced that community development contributes to social movements with significant changes in rural development, especially in developing countries [28]. Community empowerment impacts improving the community's economy and affect the environment, social structure, and community's attitude.

\subsection{Community Empowerment Communication with Innovation Adoption}

The concept of empowerment requires planning in solving problems so that solutions emerge. Top-down planning can apply several communication models. Three communication models are considered capable of influencing innovation practices: First, the objective or transmission model. Second, subjective or receiveroriented models. Third, the network or negotiation model [13]. Empowerment of farming communities must also go through irrigation to increase agricultural production. Through this, the production potential in the agrarian sector is quite significant in the welfare of society which will allow growth in yields and profitability of agricultural production, increase soil fertility and contain soil degradation, help maintain soil 
moisture, and increase fertility which of course will affect crop growth [29].

The innovation development process consists of all decisions, activities, and impacts that occur from the lap of a need or problem through the research, development, and commercialization of innovation. The consequence is that diffusion of innovation can be implemented. This level of innovation is considered to have advantages and advantages from an economic point of view. First, the story of an individual is looking at creation depends on the rate at which it is adopted. Innovation cannot be separated from opinion leaders as agents of change [30]. Opinion leaders have a role in the innovation process in the agricultural sector. To persuade, provide knowledge about innovation. An opinion leader is how the individual can influence attitudes, behavior and provide good agrarian examples. Opinion leader as social perception, ability in abstract thinking, emotional stability, as a supervisor, a guide for innovation in the farming sector and is considered a media exposure [30].

The agricultural journey in the Maju Jaya Farmer Group, Pinang Jaya Village, has evolved the adoption of agricultural innovation. Society develops dynamically, which leads to a better purpose. An environmentallyfriendly form of agriculture, but capable of increasing agricultural yields significantly. Through innovation, agriculture will not only be oriented towards the welfare of the community. However, it can carry out empowerment in the broader direction as applied to regions and even other countries because the output of agricultural development communication is the empowerment of farming communities, not only changing views on innovation but also having implications on the role of interactive, constructive, evolutionary communication [11].

Implicitly, communication designs innovation. This study found that development communication was carried out to empower farming communities with the form of njagong communication and word of mouth between residents. Word of Mouth (WoM) is providing informal socialization to citizens while chatting together. Word of Mouth is a form of word of mouth, which uses little or no cost [27]. That is a traditional community, the element of closeness to who is conveying also influences the message received or not.

Kotler [27] stated that WoM is a communication process by providing personal and group recommendations. WoM also shows the close relationship between the communicant and the communicator. The implementation of agriculture in Pinang Jaya Village is not entirely modern but still conventional logic towards semi-modern. This can be seen from the tools used are not entirely modern, but there are still many traditional ones (still needing the touch of a human hand). In cultivating rice, it is known as 'stretcher' manually, not using tools/technology.
Meanwhile, for the harvesting results, the blower technology is used. Agriculture in Pinang Jaya Village, as the initial capital for farming, is still being carried out alone. This means that there is no role for the government to provide money at the beginning of agriculture. But farmers do a strategy by selling livestock as initial capital for agriculture, or borrowing from banks, even though they are at interest. Agricultural instructors from the Bandar Lampung City Agriculture Office also provided outreach to residents about plant pest diseases, how to deal with plant pests, and build agrarian access. However, this socialization was less intensive because it was only done for socialization, no concrete action was taken, and it was carried out seasonally and was not sustainable.

Every agricultural sector run by farmers has not been connected online to directly connect agrarian extension agents, farmers, distributors, etc. Weakness between elements to join the network is constrained considering that based on the monograph of Kelurahan Pinang Jaya, the human resources with higher education are very lacking, and there are not many college graduates. Only a few are still studying at university. This means that the communication carried out is still face to face, meaning that the Word of Mouth has not been connected with all parties online.

The current development communication only focuses on how to improve the welfare of the community. Long-term needs must be able to use information technology so that the planting time is short and the yields are productive. In this context, the role of communication is an activity that seeks to empower people who must be connected to the internet network. So the development of the farming community must be oriented towards education that agriculture is very sustainable, be it empowerment, community welfare, and the connection of technology and information. Sustainable agriculture is the production of agricultural products by utilizing resources. The sustainability aspect of agriculture includes economic factors for income, social factors for welfare, environmental factors for the stability of natural ecosystems.

Based on researchers' observations, the development of agriculture in Bringin Raya Village carried out by the Maju Jaya farmer group, seen from the dynamics of the community's social conditions, has increased significantly. It can be seen that the arid land can be planted with rice, from once a year to two harvests a year until the construction of drilled wells which are then channeled to agricultural lands with a rotary irrigation system.

This shows that economic development is already going well. This is in line with what Everet M. Rogers said that empowering society requires innovation [31]. The innovation development process consists of all decisions, activities, and their impacts that occur from 
the lap of a need or problem. Two things make agriculture in Pinang Jaya Village require communication with information technology systems. First, today's communication is still traditional (face to face) and (Word of Mouth). However, this has not resolved the problems and dynamics of the existing rural communities. Therefore, innovation is needed for agriculture. By adopting new technology, agricultural extension agents, village officials, steak holders, farmers, opinion leaders must find solutions related to agriculture to get a large number of yields and good quality harvests.

\section{CONCULSION}

Based on the description of the research analysis results, it can be concluded that the community empowerment model through the concept of urban farming in the Maju Jaya Group, Pinang Jaya Village, Bandar Lampung City has been going well. However, there are some unfulfilled needs that can become a problem or obstacle in empowering the community in the Maju Jaya Farmer Group; this is seen by using the CIPOO approach (Context, Input, Process, Output, Outcome), which is already running quite well.

When viewed from the institutional aspect, management system aspects, organizational aspects, and aspects of mastery of empowerment materials in the Maju Jaya Group as a reformer agent, it has gone well, although there are several obstacles. Work programs and partnerships have been established with external parties, both government and private. In the organizational part, the Maju Jaya Group also experiences an increase in productivity every year. This is indicated by the ongoing empowerment activities, even though there are several obstacles/obstacles. In addition, the Maju Jaya Group as a reforming agent, is an established agent and has established partnerships with various parties, both government and private.

This study also found that development communication was carried out to empower farming communities with the form of njagong and word of mouth communication between residents or known as the Word of Mouth. Word of Mouth (WoM) is providing informal socialization to citizens while chatting together. Word of Mouth is a form of word of mouth, which costs little or no cost. A traditional community element of closeness to who is conveying also influences whether the message is received.

\section{REFERENCES}

[1] Martin Bailkey. 2000. Farming Inside Cities: Entrepreneurial Urban Agriculture in the United States. Lincoln Institute Product Code: WP00JK1

[2] Warren, E., Hawkesworth, S., and Knai, C.
(2015). Investigating the association between urban agriculture and food security, dietary diversity, and nutritional status: a systematic literature review. Food Policy 53, 54-66. doi: 10.1016/j.foodpol.2015.03.004

[3] Dimitri, C., Oberholtzer, L., and Pressman, A. (2016). Urban agriculture: connecting producers with consumers. Br. Food J. 118, 603-617. doi: 10.1108/BFJ-06-2015-0200

[4] Aragon, N. U., Stuhlmacher, M., Smith, J. P., Clinton, N., and Georgescu, M. (2019). Urban agriculture's bounty: contributions to phoenix's sustainability goals. Environ. Res. Lett. 14:105001. doi: 10.1088/1748-9326/ab428f

[5] Grebitus, C., Printezis, I., and Printezis, A. (2017). Relationship between consumer behavior and success of urban agriculture. Ecol. Econ. 136, 189-200. doi: 10.1016/j.ecolecon.2017.02.010

[6] Mardikanto, Totok \& Soebiato, Poerwoko. (2013). Pemberdayaan Masyarakat: Dalam Perspektif Kebijakan Publik. Bandung: ALFABETA

[7] Freedman, D. A., Vaudrin, N., Schneider, C., Trapl, E., Ohri-Vachaspati, P., and Taggart, $\mathrm{M}^{\circ}$. (2016). Systematic review of factors influencing farmers' market use overall and among lowincome populations. J. Acad. Nutr. Dietetics 116, 1136-1155. doi: 10.1016/j.jand.2016.02.010

[8] Firth, C., Maye, D., and Pearson, D. (2011). Developing "community" in community gardens. Local Environ. 16, 555-568. doi: 10.1080/13549839.2011.586025

[9] Zainal, A., \& Hilmi, G. (2019). The Influence of Emotional Intelligence and Motivation toward Agricultural Extension Worker's, Performance at Agricultural Office of Tanggamus District. Jurnal Penyuluhan 15 (1), 34-42.

[10] Kramer, M. W. (2002). Communication in a community theater group: Managing multiple group roles. Communication Studies, 53(2), 151-170.

https://doi.org/10.1080/10510970209388582

[11] Morissan. 2013. Teori Komunikasi: Individu Hingga Massa. Jajarta: Kencana Prenadamedia Group

[12] Novek, E. M. (1999). Communication and community empowerment. Peace Review, 11(1), 61-68. https://doi.org/10.1080/10402659908426231

[13] Zainal, A., \& et al. (2019). Community Development Communication Model And Improving The Role Of Agropolitan Institutions. International Journal of Scientific and Technology Research, 8(12) :, 2028-2034.

[14] Hunold, C., Sorunmu, Y., Lindy, R., Spatari, S., and Gurian, P. (2017). Is urban agriculture financially sustainable? An exploratory study of small-scale market farming in Philadelphia, 
Pennsylvania. J. Agric. Food Syst. Commun. Dev. 7, 51-67. doi: 10.5304/jafscd.2017.072.012

[15] Usman,Sunyoto.2003.Pembangunan dan pemberdayaan Masyarakat. Yogyakarta: Pustaka Pelajar

[16] Moleong, Lexy. 2005. Metode Penelitian Kualitatif. Bandung: Remaja Rosdakarya.

[17] Fatemeh Molaei Fini, A. A. S. F. (2015). A Study on the Relationship between Communication Skills and Mental Health and Job Performance, 4(4), 270-275. Retrieved from http://worldofresearches.com/ojs-2.4.41/index.php/ajps/article/view/241

[18] DeHaan, L. R. (2015). "Perennial crops are a key to sustainably productive agriculture," in Food Security: Production and Sustainability. Institute on Science for Global Policy, ISGP Academic Partnership with Eckerd College. Available online at: https://www.scienceforglobalpolicy.org

[19] Sulistyani, Teguh Ambar. 2004. Kemitraan Dan Model-Model Pemberdayaan. Cetakan Pertama. Yogyakarta: Gava Media.

[20] Mulyana, Dedy. (2007). Ilmu Komunikasi Suatu Pengantar. Bandung: PT Remaja 22 RosdaKarya

[21] Parker, A. R. (2016). Conflict Resolution Behaviors and the Affect of Identity Standards and Empowerment Needs on Individuals Using External Augmentative and Alternative Communication Devices, (39). Retrieved from http://nsuworks.nova.edu/shss_dcar_etd/39/ Kaufman,Jerry

[22] Paramitha, R. A. D. (2013). Pola Komunikasi Komunitas Save Street Child Surabaya dalam Menarik Minat Anak Jalanan Untuk Terlibat Sebagai Anak Didik Pada Program Pengajar Keren, 1, 1-11. Retrieved from ubrawijaya.academia.edu/AParamitha

[23] Johnson, David W. \& Johnson, Frank P. (2012). Dinamika Kelompok: Teori dan Keterampilan. Jakarta: PT. INDEKS

[24] Biljsma, T. (2015). Cultural Change by Speech: Team Learning and the Role of Interaction, 7790. https://doi.org/10.1007/978-3-319-07434-4

[25] Arifin, Bambang S. (2015). Dinamika Kelompok. Bandung: CV PUSTAKA SETIA

[26] Heriawan, S. (2016). Pola Komunikasi Kelompok Pada Komunitas Scooter "Vespa" dalam Menjalin Hubungan Solidaritas (Studi Deskriptif Kualitatif Pada Komunitas Ikatan Scooter Wonogiri di Wonogiri), 1-12.

[27] Kriyantono, R. (2006). Teknik Praktis Riset Komunikasi. Jakarta: Kencana.

[28] Smith, J. P., Li, X., and Turner, B. L. (2017). Lots for greening: identification of metropolitan vacant land and its potential use for cooling and agriculture in phoenix, AZ, USA. Appl. Geogr. 85, 139-151. doi: 10.1016/j.apgeog.2017.06.005
[29] Wilhelm JA, Smith RG (2017) Ecosystem services and land sparing potential of urban and periurban agriculture: A review. Renew Agric Food Syst 33:481-494.

[30] Grebitus C, Chenarides L, Muenich R and Mahalov A (2020) Consumers' Perception of Urban Farming-An Exploratory Study. Front. Sustain. Food Syst. 4:79. doi: 10.3389/fsufs.2020.00079

[31] Cowley, E., and Mitchell, A. (2003). The moderating effect of product knowledge on the learning and organization of product information. J. Consum. Res. 30, 443-454. doi: $10.1086 / 378620$ 